\title{
THE PORTRAIT OF MARKET LEADER IN FLOWER MARKET VENDORS AT PASAR RAWA BELONG
}

\author{
R.A. Aryanti W. Puspokusumo \\ Management Department, School of Business Management, BINUS University \\ Jln. K. H. Syahdan No. 9, Palmerah, Jakarta Barat 11480 \\ rpuspokusumo@binus.edu
}

\begin{abstract}
A good prospect in flowers' business has made many newcomers from different cities interested in trying the opportunity to become a succesful florist. Since Pasar Rawa Belong has grown up and become more well-known as the marketing and promotion center for flowers, it creates a conducive and atmospheric place to start the business. Many florists in Pasar Rawa Belong have made big profits from the businesses. It can be said that they all are successful florists. However, there will be barely a single florist who is considerately leading forward in the competitive environment. An observation through population of all florists in Pasar Rawa Belong and samples of 50 florists was done in order to find the forthcoming market leader. The method used in observing florists in Pasar Rawa Belong was survey and interview. Next, the results were summarized and analyzed based on certain theoremes from textbooks, articles, and online documents. The theorems are mostly related to management aspects of a competitive and conducive environment while operating a business. According to the data, Yurie Florist, Kusumawardani, and Anadisha come out as the market leaders in 2011 since they have the highest sales per month or beyond 100 million. Meanwhile, no more than 16 percent of florists in Pasar Rawa Belong are able to gain profit of more than 100 million rupiahs per month. Yurie Florist, Kusumawardani, and Anadisha have wide-scale of distribution channels and sells imported flowers which support their high sales. The sales become indicator to determine market share of the shops. The market share itself is decisive indicator to determine the market leader.
\end{abstract}

Keyword: flowers, florist, market vendor, market leader, Pasar Rawa Belong

\begin{abstract}
ABSTRAK
Prospek bagus dalam bisnis bunga membuat banyak pendatang dari berbagai kota tertarik untuk mencoba kesempatan untuk menjadi penjual bunga yang sukses. Karena Pasar Rawa Belong telah tumbuh dan menjadi lebih terkenal sebagai pusat pemasaran dan promosi untuk bunga, hal itu menciptakan tempat yang kondusif dan bagus untuk memulai bisnis. Banyak toko bunga di Pasar Rawa Belong memperoleh keuntungan besar dari bisnis. Dapat dikatakan bahwa mereka semua adalah toko bunga yang sukses. Namun, ada toko bunga tunggal yang dianggap maju memimpin dalam lingkungan yang kompetitif. Pengamatan dari populasi seluruh toko bunga di Pasar Rawa Belong dan sampel dari 50 toko bunga dilakukan untuk menemukan pemimpin pasar mendatang. Metode yang digunakan dalam pengamatan toko bunga di Pasar Rawa Belong adalah survei dan wawancara. Selanjutnya, hasil dirangkum dan dianalisis berdasarkan teori dari buku teks, artikel, dan dokumen online. Sebagian besar teori terkait dengan aspek pengelolaan lingkungan yang kompetitif dan kondusif saat mengoperasikan bisnis. Berdasarkan data, Yurie Florist, Kusumawardani, dan Anadisha keluar sebagai pemimpin pasar pada tahun 2011 karena mereka memiliki penjualan tertinggi per bulan atau melampaui 100 juta. Sementara itu, tidak lebih dari 16 persen dari toko bunga di Pasar Rawa Belong dapat memperoleh keuntungan lebih dari 100 juta rupiah per bulan. Yurie Florist, Kusumawardani, dan Anadisha memiliki skala-luas saluran distribusi, dan menjual bunga impor yang mendukung penjualan tinggi. Penjualan menjadi indikator untuk menentukan pangsa pasar toko-toko. Pangsa pasar adalah indikator penentu dalam menentukan pemimpin pasar.
\end{abstract}

Kata kunci: bunga, penjual bunga, penjual, pemimpin pasar, Pasar Rawa Belong 


\section{INTRODUCTION}

The demand for flowers in Indonesia has been increasing 15\%-20\% annually (Asian Development Bank, 2006:83). This demand escalation is equally to the human's needs of flowers. Today, people do not merely use flowers as a symbol to express love. Flowers also have various meaning and usefulness. For example, the Frangipani flower is mostly used to express condolences, while yellow rose is used as a symbol of friendship. Others may be used to express gratefulness, to touch up internal decoration, and to be used in wedding ceremony. Hence, flowers undoubtedly play an important role in human's life.

In fact, strategic geographic location and physical geographic features of Indonesia have brought advantages in overcoming domestic flowers demand. It provides possibilities for Indonesian people to develop floriculture comprising cut flower industry. Inevitably, good prospect of flower industry has interested many Indonesians to create business chain in this sector. They joined florist community that has existed in Pasar Rawa Belong, West Jakarta and build more competition in the market. A more challenging competition between florists in Pasar Rawa Belong encourages author to take notice and make analysis that may lead to an answer of which Rawa Belong florist who could potentially become the market leader in 2011.

The purposes of the research are to find out the market leader among florists in Rawa Belong, discover the factors that make the florist become the market leader; find out vision and mission of the market leader. Nevertheless, the research did not run as planned. There are some obstacles during the research, such as many florists refused to be interviewed; most owners of the flower shop are not available to be interviewed; difficulties in scheduling the research; unpredictable weather. Fortunately, the paper could be done punctually based on deadline.

\section{Four Functions of Management}

According to Dyck \& Neubert (2009), management is coordination and oversight of the work activities of others so that their activities are completed efficiently and effectively. Planning, organizing, leading, and controlling are the four main functions of management. These functions are first identified by Henri Fayol almost a century ago, and they are commonly used as the organizing framework for management courses and textbooks.

To David (2011), the four main functions of management are Planning is an act of identifying an organization's goals and strategies and allocating the appropriate organizational resources required to achieve them. Plans are document that outline how goals are going to be met. In the terms of breadth, there are strategic plans and operational plans. Strategic plans apply to an entire organization and establish the organization's overall goals. Operational plans encompass a particular operational area of organization. Strategic plans are usually long-term or beyond three years. Operational plans are usually covering one year or less. Lower-level managers do operational planning, while upper-level managers do strategic planning. Developing a vision statement is often considered the first step in strategic planning, preceding even development of a mission statement. Vision statement usually answers the question "What do we want to become?"

Mission statements are enduring statements of purpose that distinguish one business from other similar firms. A mission statement identifies the scope of a firm's operations in product and market terms. A clear mission statement describes the values and priorities of an organization. Developing a mission statement compels strategists to think about the nature and scope of present operations and to assess the potential attractiveness of future markets and activities. A mission statement broadly charts the future direction of an organization. A mission statement is a constant reminder to its employees of why the organization exists and what the founders envisioned when they put their fame and fortune at risk to breathe life into their dreams. 
Organizing ensures that tasks have been assigned and a structure of organizational relationships is created to facilitate meeting organizational goals. More specifically, organizing function is done with the help of the following steps Identification of activities. All the activities which have to be performed in a concern have to be identified first. For example, preparation of accounts, making sales, record keeping, and quality control. In Departmentally organizing the activities, the manager tries to combine and group similar and related activities into units or departments. The organization of dividing the whole concern into independent units and departments is called departmentation.

In Classifying the authority, manager likes to classify the powers and its extent to the managers. The activity of giving a rank in order to the managerial positions is called hierarchy. The top management is into formulation of policies, the middle level management is into departmental supervision and lower level management is into supervision of foremen. The clarification of authority helps in bringing efficiency in the running of a concern. It may also be helpful in avoiding waste of time, money, effort, and in avoidance of duplication or overlapping of efforts. It could bring smoothness in a concern's working.

Another point will be coordination between authority and responsibility. Relationships are established among various groups to enable smooth interaction toward the achievement of the organizational goal. Each individual is managed to be aware of his/her authority and he/she knows whom they have to take orders from and to whom they are accountable and to whom they have to report. A clear organizational structure is drawn and all the employees are forced to be aware of it. (MSG Team)

As written in Robbins \& Coulter (2011), they mention about the POLC (Planning, Organizing, Leading and Controlling) the key to successful managing the organization.

\section{Analyzing External and Internal Factors (SWOT)}

SWOT stands for Strengths, Weaknesses, Opportunities, and Threats. A SWOT analysis examines an organization's internal strengths and weaknesses in light of external opportunities and threats. Strengths are valuable or unique resources that an organization has or any activities that it does particularly well. Weaknesses mean lack of specific resources or abilities that an organization needs to do well. Opportunities are conditions in the external environments that have the potential to help managers in meeting or exceeding organizational goals. Threats are conditions in the external environments that have the potential to prevent managers from meeting organizational goals.

\section{RESEARCH METHODS}

Here is the explanation about population and samples used for the research. The population is all the florists in Pasar Rawa Belong, West Jakarta, and Samples used are 50 Florists in Pasar Rawa Belong. The research took place on February 13, 2013 until April 17, 2013. The questionnaires were filled in at Pasar Rawa Belong at Sulaiman Street 50, Kebon Jeruk, West Jakarta.

Primary data needed in the research were obtained using survey method or by spreading 50 questionnaires to 50 florists in Pasar Rawa Belong. The next step was interviewing the market leader candidates in order to speculate the next market leader in 2011. The interview concerned about marketing and management strategies in selling flowers. Meanwhile, secondary data were obtained from textbooks, articles, and online documents. 
Based on the questionnaires result, the quantitative data collected were summarized into chart or diagram using statistical software called Statistical Package for the Social Sciences (SPSS). Then, the chart or diagram was analyzed to find out the market leader candidates. Finally, information obtained from interviewing the market leader candidates were compared with related theorems to achieve a conclusion.

\section{RESULTS AND DISCUSSION}

Pasar Rawa Belong is a market which only sells agricultural products, especially flowers. Rawa Belong is the centre of flower shops in Jakarta. It is located at Sulaiman street number 50 Kebon Jeruk West Jakarta. The market was firstly developed by Unit Pelaksana Teknis (UPT) division of Agricultural and Forestry Department.

In the beginning, there are no more than 76 flower shops and three cut leaves shops in Pasar Rawa Belong. However, in 1998, the new building which is located across the old building was built as there was increasing number of florists who entered the market. Too many florists in Pasar Rawa Belong had caused the strict competition occurred and some florists could not survive. Thus, there are hardly 50 flower shops which really exist up to now. Furthermore, in order to maintain the price stability and to fulfill the demands of flowers, in 2004 "Gedung Lelang" was built on 200 meter square land.

Florists in Pasar Rawa Belong offers various kinds of flowers. Orchids, subtropical flowers, various leaves for ornaments, fertilizers, pots, and other agricultural facilities are the examples. Large variety of products and services are offered in Pasar Rawa Belong these days. For this reason, it is not surprisingly that the market activity never stops. The busiest transaction comes out at $3.00 \mathrm{am}$ until $7.00 \mathrm{am}$ and in the weekend.

Vision statement is to maintain and enhance its existence as a Promotion Centre and Marketing of Agricultural and Forest Product and Prima Excellent in Providing Services Agribusiness. Mission statements are to improve the appearances in order to become the agro-tourism destination, provide services in terms of facilities, infrastructure and information to the perpetrators of agribusiness, producers, consumers and public in the business; create better business conditions in agriculture and forestry and also in conducive atmospheres to develop and enhance a partnership, capital, marketing and promotion; improve the welfare of farmers and agents of agricultural and forest products by motivating them as well as to create the partnerships among florists which will ultimately improve their living standards.

\section{Analysis}
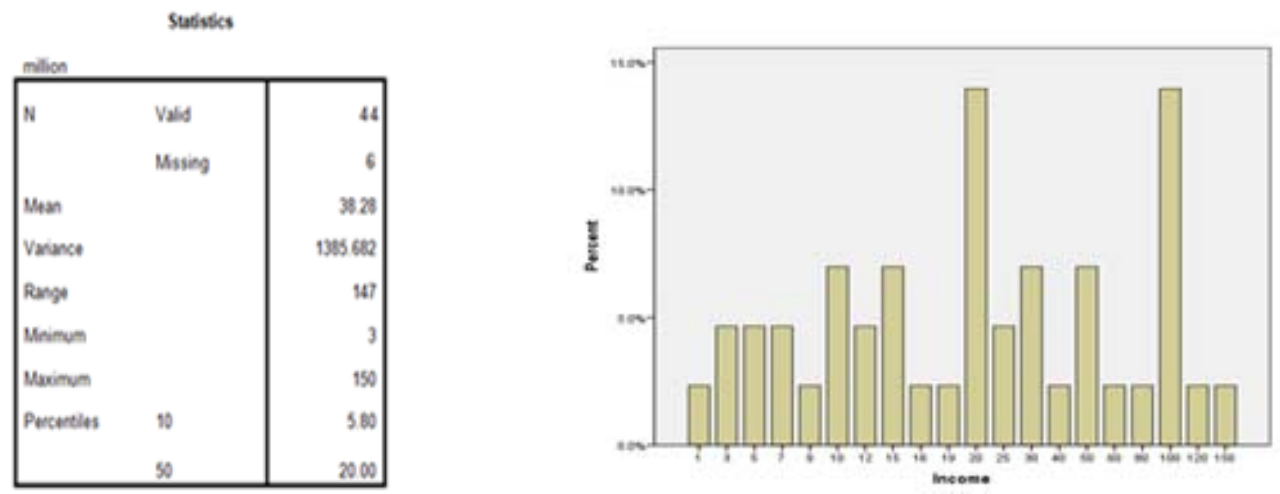

Figure 1 Sales or Income per Month of Each Flower Shop in Pasar Rawa Belong 
The diagram above is made using Statistical Package for the Social Sciences (SPSS). It shows the sales or income per month of each flower shop in Pasar Rawa Belong. The data are specifically listed in the following table.

Table 1 Sales or Income per Month of Each Flower Shop in Pasar Rawa Belong

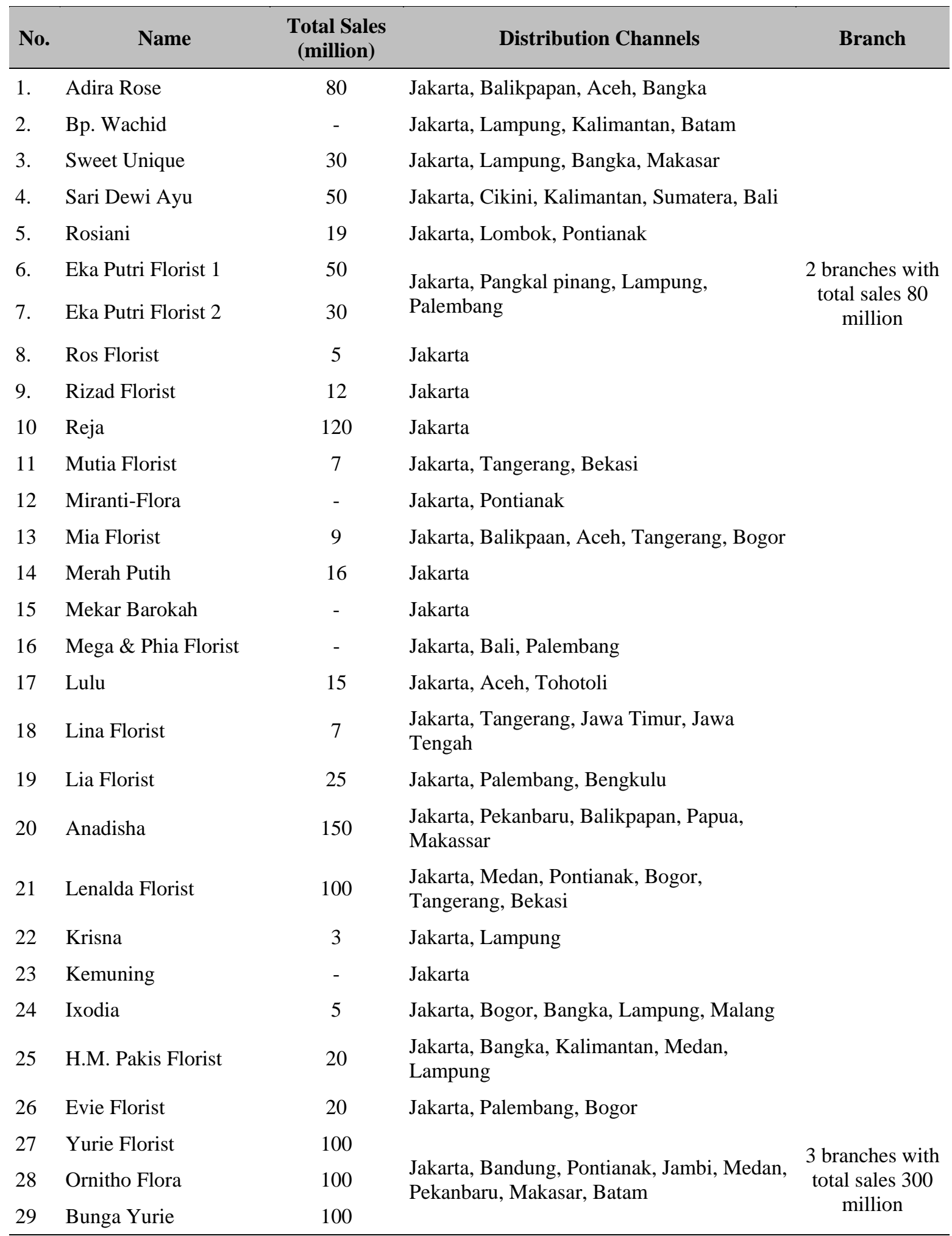




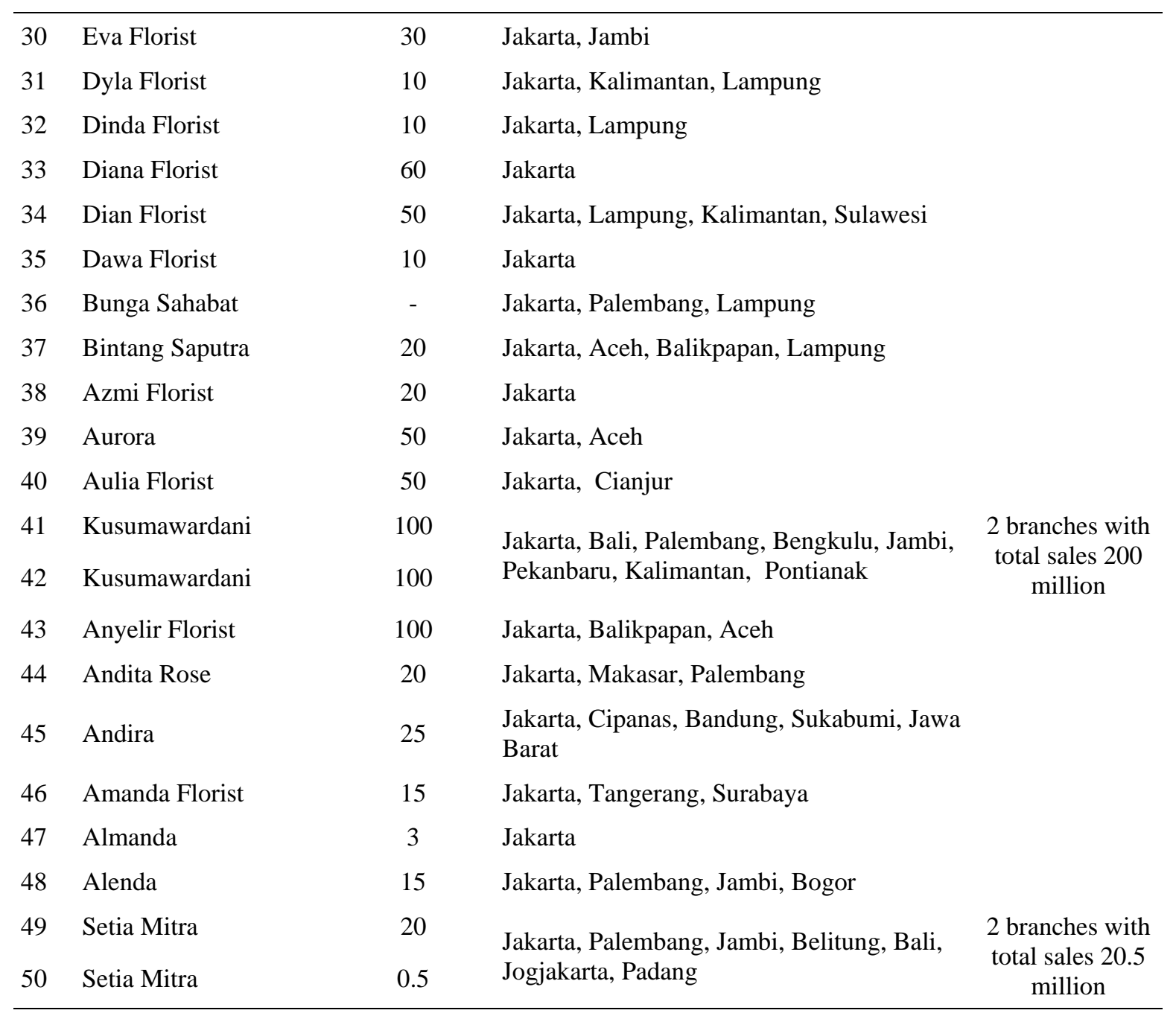

Data in the table show that there are three florists with the highest average sales per month. They are Yurie Florist, Kusumawardani, and Anadisha, whose sales are 300 million, 200 million and 150 million each per month. Additionally, distribution channel may considerately become one of the factors that support the sales of the shop. Yurie Florist, Kusumawardani, and Anadisha have at least four distribution channels to cities outside Jakarta.

"The practice of adaptive selling is the altering of sales behaviors during a customer interaction or across customer interactions based on perceived information about the nature of the selling situation."

The theorem above implies that the ability to adapt with customers' needs is very important since it is one of key success factors in selling. During the observation, it is known that the demand of flowers is increasing and become more various. These days, customers are requesting not only local flowers, but also imported flowers. Therefore, some florists provide many kinds of flower, either local flowers or imported flowers from foreign countries. 


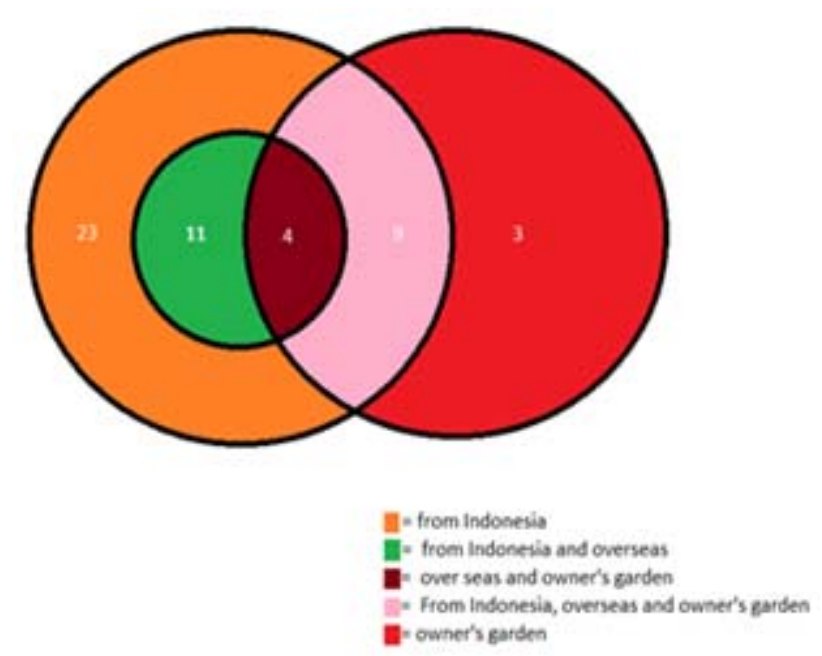

Figure 2 Kinds of Flower Sold in Pasar Rawa Belong

The diagram above shows that there are only fifteen florists or thirty percents of florists in Pasar Rawa Belong who get the stock of flowers from cities in Indonesia or their own garden, and also foreign countries. They are represented by green and red colours. Yurie Florist, Kusumawardani, and Anadisha are three of the fifteen florists that sell imported flowers. The customers find easiness to get the imported flowers in those shops. It also be another factors that increase the sales.

According to the theorem, the total sales are proportional with the percentage of sales in a region. Hence, the more sales, the more portion that a flower shop has in Pasar Rawa Belong. Shop with the biggest number of market share will be dominant in the market for the same section which means it has probability to become the market leader. For this reason, Yurie Florist, Kusumawardani, and Anadisha come up as the next market leader in 2011.

\section{Yurie Florist}

Yurie Florist was first opened in 2001. At first, the owner of Yurie Florist was joining with Bina Flora in selling flowers. After he got enough profits, he decided to open his own shop without cutting off his connection with Bina Flora even until now.

Yurie Florist has very obvious vision statements, even the short-term and long-term vision. The short-term vision is to increase the selling. For that reason, the owner defined related short-term mission statements. The mission statements are to find more supplier as well as more various flowers and widen the promotion through trending sites. The long-term vision of Yurie Florist is to expand the shops and open new branches in Pasar Rawa Belong. Regarding the long-term vision statement, he also explained the mission statement about satisfying the customers, and thereafter they could reach the target of income. The short-term vision supports the long-term vision which is the most important target to be accomplished. The vision and mission statements help the related parties to determine strategic plans easier. Indeed, the owner of Yurie Florist develops strategic plan in terms of achieving the long-term vision statement. Yurie Florist provides wide variety of flowers, both local and imported, even uncommon flowers like Sorbonne, Peacock, Gerbera and Casablanca. Practically, Yurie Florist has the most complete collection of flowers in Pasar Rawa Belong. The entire things are dedicated to customers' satisfaction since Yurie Florist has targets to cover not only housewives and decorators, but also the other florists outside Pasar Rawa Belong.

Moreover, the sibling of Yurie Florist's owner helps developing the operational plans. He enlarges the distribution channels domestically. After he promoted Yurie Florist in Facebook, he also 
planned to gain more customers by promoting in Kaskus and having their own website. For the whole reasons, it can be said that Yurie Florist is very adaptive to the competitive environment since Yurie Florist has visible objectives.

In Yurie Florist, flowers are kept properly before they are sold. According to the owner, there are several things that should be well thought-out, to keep the flowers fresh. The first one is regarding the temperature. The owner said that flowers should be kept in moist place within the temperature of $13^{0}-27^{0} \mathrm{C}$. Meanwhile, cut flowers have to be placed in water-filled pots. The amount of water in the pots should also be precise for each different flower, not too little and not too much. In fact, either too much water or too little water can damage the flowers. Moreover, flowers must be kept away from ethylene gas or everything that produces ethylene gas such as vegetables and fruits. Good flowersstoring method would prevent more discarded flowers. He added that the keys of treating flowers well were the experience and patience.

There are 15 employees in total who work for the three shops which belong to the same owner, Yurie Florist, Bunga Yurie, and Ornitho. He organizes the workers based on the working hours. He allocates 5 workers in each shop for the duration of 24 hours. Three workers work on the day-shift whereas the other two workers work on the evening-shift. In point of fact, there is no certain standard to work in Yurie Florist. All are welcome and possible to work there. Even so, he gives 3months-training for every applicant before having them worked at Yurie Florist, Bunga Yurie, and Ornitho. The training is intentionally to let the applicants know and become used to what they are going to be in charge of. It covers the knowledge of flowers to be sold and some basic soft skills such as dealing with customers. It is very supportive to lead the shops accomplishing some key success factors in selling such as verbal skills, proficiency in interacting with people at all levels of a customer's organization, and listening skills. After the 3-months-training, he will evaluate the trainees if they are able to work properly. Based on the observation, it could be seen that the employees are all capable and skilled in dealing with customers.

However, Bunga Yurie still have blurred organizational structure. The owner of the shop handles all the job of every task. Furthermore, the owner does not assign particular task for every employee which cause the employee burdened with multiple job at the same time. This unclear organizational structure may adversely impact the future. Each employee will have an imprecise responsibility. If it is not fixed rapidly, it will cause wrangles among employees, either for doing the tasks or not doing the tasks.

The owner of Yurie Florist gets all his workers to do the bookkeeping. They do have been trained. Nevertheless, the more employees are in charge of bookkeeping event, the more chances that fraudulences will occur. Bookkeeping may become less valid and ineffective. If it continues, it will affect not only to defective plan forward but also to the business which may progressively be busted.

The owner of Yurie Florist is known as a friendly, wise, as well as firm person. He comes to control and organize his shop every day. When it is not possible, he will contact the employees to monitor their activity. As both the owner and also the leader of Yurie Florist, he always gives clear direction to his subordinates. Within a clear vision and mission, he leads and motivates his employees to aim the goals together.

He also had taken some big decisions that brought to improvement of his business. It inspires the employees as team members to believe that they all are capable in making their vision in reality. He gained more trust as the leader with forward-looking vision while the employees saw some progresses in the business. In addition, the employees say that they feel comfortable with the owner because of his personality. 
Yurie Florist always tries to fulfill the standard in Rawa Belong market. When there are any specific demands of flower, the owner will search and obtain those flower immediately so that he become the sole seller of that specific flower. For instance, when there are some demands for imported flowers such as Lily, Tulip, or Casablanca, he can easily obtain the flowers because he has good connection to companies that stock imported flowers. Since there are many shops in Pasar Rawa Belong, he tries to catch the customers' eye by making more shop branches (Bunga Yurie and Ornitho), providing more complete kind of flowers, and increasing the aesthetic aspect of each shop.

In distributing the product, Yurie Florist also covers many cities outside Jakarta, such as Pontianak, Makassar, Medan, Ujung Pandang, Jambi, Batam, Pekanbaru, etc. The distribution includes the marketing tasks. The owner of Yurie Florist with the help of his brother keep track of today's trend of technology. They promote Yurie Florist by using media that are available nowadays, such as internet. They make some accounts named Yurie Florist on Facebook, the most the most favorite site today, since February 2011. It is seen as an innovative approach to be a more dominant shop among the others.

Afterwards, the owner of Yurie Florist established two more branches, Bunga Yurie in 2007 and Ornitho in 2009. It is not easy to establish a new branch. The florist must see the opportunity as well as developing a good planning. The owner of Yurie Florist could see the opportunity in the market and even bring his plans into reality with doing good marketing strategy just in a short period. Because the owner of Yurie Florist can optimize his flower shops' income, Yurie Florist and its branches get the highest revenues and become florist with the biggest market share in Pasar Rawa Belong.

\section{Kusumawardani}

The owner of Kusumawardani first opened his flower shop in 1995. By catching an opportunity in 2006, she opened a new branch with the same name. Kusumawardani provides wide variety of decoration flowers, such as Roses, Casablancas, Asters, Carnations, Anthuriums, Chrysanthemums, and Orchids. Currently, both shops have the average income of 200 million rupiah per month.

During the interview, the owner of Kusumawardani stated that the vision statements of her flower shops are to earn for life and continue the business inherited. She also mentioned some mission statements is to open new branches, add more new variety of flowers, keep the quality of flowers to be sold.

Kusumawardani has its own garden and grows the imported seeds domestically in its owngarden to supply the stock of flowers. By having her own garden, the owner of Kusumawardani can easily manage the increase of market's demand for certain flowers. However, own a garden means the seeds, the soil, and some other conditions need to be managed and controlled. Growing imported seeds from foreign countries such as Holland and China may probably lead to some problems. Indonesia has tropical climate which is different from any other countries. Hence, the flowers produced are considerately different with their origins in quality and also appearance. Furthermore, own a garden means the owner of Kusumawardani would spend more time and human resources to take care of the growing flowers. The owner would have less efficiency in organizing since she has to keep an eye for both shops and garden.

Practically, there are eight workers who work in Kusumawardani in total. Each shop has four workers a day and they are divided into two shifts, day-shift and evening-shift. Educational background is the main criteria to work in Kusumawardani. It could be seen in the actual fact that there should be no less than one worker who is at least high-school graduated on every shift. In organizing the bookkeeping event, the owner of Kusumawardani barely entrusts it to two workers on 
day-shift who are by far more senior. Transactional records on the night-shift are collected and it will be copied to the journal on the day-shift. As regards two workers are entrusted, errors and cheating in bookkeeping could be minimized. Furthermore, it is easier to trace the cheating in case a misdeed occurs.

During the interview, the owner of Kusumawardani told that one of her employee had ever stolen the money from selling the flowers. The owner excused and tolerated the employee once. But eventually, the employee kept stealing the money. As consequences, it gives bad impression for employees and the owner may lose the employees' respect to her.

Kusumawardani also have a lack of sales controlling aspect. This can be seen in the way the flower shops are handled. Kusumawardani does not tend to focus in searching more costumers. He keeps the changes in her shop minimally, hoping that keeping the old system will do the same regardless the changes in the market.

\section{Anadisha}

Anadisha's owner was graduated from Binus University in 1996. In 2003, he opened the flower shop in Pasar Rawa Belong. He decided to sell flowers in Pasar Rawa Belong because he assumed that most customers will buy flowers there. He sells both local and imported flowers such as Chrysanthemums, Asters, Casablancas, Roses, and Gerberras. The imported flowers came from Holland, Singapore, and England. Meanwhile, the local flowers are from Halimun Mountain, Cipanas, Sukabumi, Bandung, and Malang. The flowers he got have higher quality since he purchased them from flower companies which have higher standard than the farmers. He later distributes the flowers to not only around Jakarta, but also other cities.

From the beginning, he has already decided the vision and mission statements of his flower shop which is to gain profit beyond average. The strategy to achieve the vision is by increasing the sales. Therefore, by applying knowledges that he got from the college, he built a website to promote his flower shop which can expand the distribution.

He has three people work for him. In the morning until evening, one of his employees accompanies him to watch the shop while the other two have night shift. As a manager, he leads his employees well. He maintains a conducive environment for the employees to work effectively. He can keep the trust of his employees and he can be strict when it is necessary.

Despite his ability in running his flower shop, he also faces some obstacles. At the first few months, he only has few customers because of his lack of experiences. He also can not identify the market's demand of flowers. Even worse, he finds it difficult to manage all of the tasks as he is the only manager of the shop until now.

Similar to Yurie Florist and Kusumawardani, there is no organizational structure in his shop, thus every employee is loaded with a lot of unspesific jobs. This may cause ineffectiveness in doing their responsibility. For example, invalid result of bookkeeping. The other obstacle is about the unstable income. The income of his flower shop is going down in unspecial days. Sometimes, he needs to think and plan more to cover up this condition to avoid bankruptcy. 


\section{CONCLUSION}

Market share is very important in determining the market leader in a region. It becomes the power for a company or organization to develop and strengthen the business. A shop with the biggest market share considerably has great reputation in the region since the products are mostly best-sellers. Within great reputation, more customers are looking for and coming to the shops.

In Pasar Rawa Belong, the top three market leaders with the biggest market share are Yurie Florist, Kusumawardani, and Anadisha. These market leaders have their own way to perform management strategies for their flower shops. Overall, they have good management abilities and strategies in achieving goals or targets. They also have good abilities and skills to adapt with current market condition and make needed changes to accomplish the goals in order to gain maximum profits. Nevertheless, as every manager does, the owner of Yurie Florist, Kusumawardani, and Anadisha have some obstacles in running their business. Most of them are the difficulties in creating the organizational structure. The florists seemingly underestimate the function of organizational structure. Eventhough this will give impact to uneffective division of labor.

\section{Suggestions for Florist}

It is important to maintain the position of market leader, as well as improve the business. The other florists also have the same opportunity to be the market leader as long as they improve their management skill. It is also better for the florists to concern about SWOT analysis. Strengths, weaknesses, opportunities, and threats (SWOT) analysis can be done with the intention of reviewing the performance of business. Florists may do strengths and weaknesses analysis focusing on past performance and present strategies such as lack in employees' organization or good at controlling stocks. The result of the analysis can be used as the next goals or targets of the business. Then, florists may examine external environment to find out opportunities and threats to accomplish the future targets or goals and make new innovation.

\section{REFERENCES}

Asian Development Bank, Ministry of Agriculture. (2006). Strategic Vision for Agriculture and Rural Development. Asian Development Bank, Manila.

Dyck, B. \& Neubert, Mitchell J. (2009). Principle of Management. China: South-Western.

David, F. R. (2011). Strategic Management. New Jersey: Pearson.

Heller, R. (2008). Effective Management Strategy. Retrieved March 15 ${ }^{\text {th }}, 2011$ from http://www.thinkingmanagers.com/management/effective-management-strategy.

Johnston, M. W. \& Marshall, G. W. (2006). Sales Force Management. New York: McGrew - Hills.

Matt. (2009). Controlling Function of Management. Retrieved March $20^{\text {th }}$, 2011 from http://www.sayeconomy.com/controlling-function-of-management/

Matt. (2009). Function of Management in business organizations. Retrieved March $20^{\text {th }}, 2011$ from http://www.sayeconomy.com/functions-of-management-in-business-organizations/ 
Mishra, M. (2010). Marketing Concepts and Technique. Retrieved March 15 ${ }^{\text {th }}, 2011$ from http://marketinginovationselfmotivatingtips.blogspot.com/2010/06/market-share.html

MSG Team. Organizing Function of Management. Retrieved March 15 ${ }^{\text {th }} 2011$ from http://www.managementstudyguide.com/organizing_function.htm.

Newbrough, E.T. (1999). Effective Maintenance. New York: McGrew - Hills.

Robbins, S.P., \& Coulter, M.K.. (2011). Management, Global Edition. 11th Edition. N USA: Pearson Higher Education.

Rothbauer, H. (2009). Leading as A Management Function. Retrieved March $11^{\text {th }}, 2011$ from http://www.suite101.com/content/leading-as-a-management-function-a124060.

Rothbauer, H. (2009). Planning as A Management Function. Retrieved March $11^{\text {th }}$, 2011 from http://www.suite101.com/content/planning-as-a-management-function-a115977 